\title{
Circulating microRNA expression profile and systemic right ventricular function in adults after atrial switch operation for complete transposition of the great arteries
}

Clare TM Lai ${ }^{1}$, Enders $\mathrm{KO} \mathrm{Ng}{ }^{2}$, Pak-cheong Chow ${ }^{1}$, Ava Kwong $^{2}$ and Yiu-fai Cheung ${ }^{1,3^{*}}$

\begin{abstract}
Background: Data on the use of circulating microRNAs (miRNAs) as biomarkers of cardiovascular diseases are emerging. Little, however, is known on the expression profile of circulating of microRNAs in congenital heart malformations with a systemic right ventricle that is prone to functional impairment. We aimed to test the hypothesis that circulating miRNA profile is altered in patients late after atrial switch operation for complete transposition of the great arteries (TGA) and further explored possible relationships between alteration of circulating miRNAs and systemic ventricular contractility.
\end{abstract}

Methods: Circulating miRNA expression profiling of serum samples from 5 patients and 5 healthy controls was performed. The results were validated in 26 patients and 20 controls using real-time quantitative reverse-transcription polymerase chain reaction for candidate miRNAs with fold changes $>3$ by expression profiling. Systemic ventricular myocardial acceleration during isovolumic contraction (IVA) was determined by colour tissue Doppler echocardiography.

Results: Compared with controls, patients had significantly lower systemic ventricular IVA $(p=0.002)$. Of the 23 upregulated miRNAs identified by profiling, 11 were validated to be increased in patients compared with controls: miR-16, miR-106a, miR-144*, miR-18a, miR-25, miR-451, miR-486-3p, miR-486-5p, miR-505*, let-7e and miR-93. Among the validated 11 miRNAs, miR-18a $(r=-0.45, p=0.002)$ and miR-486-5p $(r=-0.35, p=0.018)$ correlated negatively with systemic ventricular IVA for the whole cohort.

Conclusions: A distinct serum miRNA expression signature exists in adults with complete TGA after atrial switch operation, with serum miR-18a and miR-486-5p being associated with systemic ventricular contractility.

Keywords: MicroRNA, Transposition of the great arteries, Atrial switch, Systemic ventricular function

\section{Background}

MicroRNAs (miRNAs) are small non-coding singlestranded RNAs with 19 to 24 nucleotides. These form complementary pair with specific target mRNAs to negatively regulate their expression via translational repression or degradation [1]. While alteration of tissue

\footnotetext{
* Correspondence: xfcheung@hku.hk

'Division of Paediatric Cardiology, Department of Paediatrics and Adolescent Medicine, The University of Hong Kong, Hongkong, China

${ }^{3}$ Division of Paediatric Cardiology, Department of Paediatrics and Adolescent Medicine, The University of Hong Kong, Queen Mary Hospital, 102, Pokfulam Road, Hong Kong, China

Full list of author information is available at the end of the article
}

miRNA expression has been well documented in malignancies [2,3], the role of miRNA in cardiovascular development [4], cardiac remodeling and heart failure [5,6], and myocardial injury [7] is beginning to be recognized.

In determining the potential role of miRNAs in cardiovascular diseases, earlier studies have reported distinct profiles of differential tissue miRNA expression in human $[8,9]$ and experimental models of heart failure $[6,10]$. Further cardiac tissue-based studies have provided evidence of involvement of selective miRNAs in myocardial hypertrophy [11,12], regulation of cardiac apoptosis [13], regulation of cytoskeleton of cardiomyocytes and 
cardiac extracellular matrix [11], and neurohormonal activation [14,15], all of which contribute to adverse cardiac remodeling.

Recent studies have shown that miRNAs released into the blood stream are stable and measurable $[16,17]$. Importantly, data in human subjects on the use of a signature circulating miRNAs as novel markers of cardiovascular diseases are emerging. Elevation of plasma cardiac-specific miRNA-208a has been shown to be potentially useful for early diagnosis of myocardial infarction [18], while plasma miR423-5p has also been found to be increased in heart failure patients with reduced left ventricular (LV) ejection fraction [19]. Additionally, a signature circulating miRNA expression profile has been reported in hypertensive patients [20]. These encouraging data, albeit limited to date, provide evidence that circulating miRNAs may be potential biomarkers of cardiovascular diseases, in particular LV diseases.

Little, however, is known on the expression profile of circulating microRNAs in congenital heart malformations with a systemic right ventricle. In patients with complete transposition of the great arteries (TGA) after atrial switch operation, late systemic right ventricular (RV) dysfunction is well documented [21,22]. There is further evidence to suggest that deterioration of systemic RV function and clinical status is progressive [22,23]. In this study, we tested the hypothesis that the circulating miRNA profile is altered in patients late after atrial switch operation and further explored the relationships between alteration of circulating miRNAs and systemic ventricular contractility.

\section{Methods}

\section{Subjects}

Twenty-six patients with complete TGA who had undergone Mustard or Senning procedure were recruited. The following demographic and clinical variables were collected: age at study, associated cardiac abnormalities, age at and type of operation, duration of follow-up since surgical repair, and current cardiac medications. Twenty healthy subjects were recruited as controls. The Institutional Review Board of The University of Hong Kong/ Hospital Authority West Cluster, Hong Kong, approved the study and all study subjects gave written, informed consent.

\section{Serum collection and small RNA isolation}

Blood obtained by venepuncture was centrifuged at $3000 \mathrm{rpm}$ for 15 minutes immediately after collection. The centrifuged serum was transferred to another tube and re-spun once again to remove further debris. The serum samples were stored at $-80^{\circ} \mathrm{C}$ until assay. Total RNA was extracted using Trizol LS reagent (Invitrogen, Carlsbad, California, USA) and miRNeasy Mini Kit (Qiagen, Hilden, California, USA) according to manufacturer's in- structions with minor modifications [24]. Briefly, $500 \mu \mathrm{l}$ of serum was mixed with $1 \mathrm{ml}$ Trizol LS reagent and the aqueous phase of the mixture was transferred to a new tube and centrifuged after addition of chloroform. 1.5 volume of absolute ethanol was added to the aqueous phase and the mixture was applied into miRNeasy spin column as per manufacturer's instructions. RNA was eluted with $30 \mu \mathrm{l}$ RNase-free water. The concentration of RNA was quantified by NanoDrop ND-1000 Spectrophotometer (Nanodrop, Wilmington, Delaware, USA).

\section{MiRNA profiling}

To study differential miRNA expression in TGA patients post atrial switch operation, we performed miRNA expression profiling of the serum samples from 5 patients and 5 age- and sex-matched controls using TaqMan Low Density Array Human MicroRNA Panel (Applied Biosystems, CA, USA), which contains $>754$ well-established miRNA assays including the respective reversetranscription primers, PCR primers, and TaqMan probe. These 5 patients had the worst systemic RV function as assessed by echocardiography. For each array assay, $80 \mathrm{ng} / \mu \mathrm{l}$ serum miRNA was used for the reversetranscription reaction with a pool of Megaplex RT primers. TaqMan-based qPCR profiling was performed using TaqMan Universal PCR Master Mix (Applied Biosystems) in ABI PRISM 7900 HT system (Applied Biosystems) according to the manufacturer's instructions. U6 small nuclear RNA in the array was selected as the internal normalization transcript. The $\Delta$ cycle of threshold $(\mathrm{Ct})$ was calculated by subtracting the averaged $\mathrm{Ct}$ values of $\mathrm{U} 6$ from the $\mathrm{Ct}$ values of the miRNA of interest. $\Delta \Delta \mathrm{Ct}$ was then calculated by subtracting $\Delta \mathrm{Ct}$ of the control from $\Delta \mathrm{Ct}$ of the sample. Fold change of the miRNA was calculated by the equation: $2^{-\Delta \Delta \mathrm{Ct}}$. Upand down-regulation of miRNAs with fold changes $>3$ were selected for validation in the entire patient cohort.

\section{Real-time quantitative reverse-transcription polymerase chain reaction}

To validate the findings of miRNA profiling, we measured the expression levels of differentially expressed miRNAs using Real-Time Quantitative Reverse-Transcription Polymerase Chain Reaction (qRT-PCR) in all of the 26 patients and 20 controls. SYBR green qRT-PCR assay was used for individual miRNA quantification [24]. Briefly, $30 \mathrm{ng}$ of serum RNA was polyadenylated by poly(A) polymerase and reversely transcribed using miScript Reverse Transcription Kit (Qiagen) according to manufacturer's instructions. Real-time $\mathrm{qPCR}$ was performed using miScript SYBR Green PCR Kit (Qiagen) in ABI PRISM 7900 Real-time PCR system (Applied Biosystems). Amplification was performed with the miScript Universal primer provided by manufacturer and the miRNA-specific 
forward primers. The miRNA-specific primer sequences for qRT-PCR were listed in Additional file 1: Table S1. The amplification profile was $95^{\circ} \mathrm{C}$ for 15 minutes, followed by 45 cycles of $94^{\circ} \mathrm{C}$ for 15 seconds, $55^{\circ} \mathrm{C}$ for 30 seconds, and $70^{\circ} \mathrm{C}$ for 30 seconds. At the end of the PCR cycles, melting curve analyses were performed. The expression levels of miRNAs were normalised to U6 small nuclear RNA (RNU6B) level [24]. The fold change of the miRNA was calculated as aforementioned.

\section{Echocardiographic assessment}

Transthoracic echocardiography was performed using the Vivid 7 ultrasound system (General Electric Vingmed Ultrasound, Horten, Norway). Echocardiographic recordings were made in three cardiac cycles and the average was used for statistical analysis. Offline analyses were performed using the EchoPAC software (General Electric, Horten, Norway). Colour tissue Doppler echocardiography was used to measure the relative load independent index of systolic function, myocardial acceleration during isovolumic contraction (IVA) [25], of the systemic ventricle. Colour-flow mapping was used for the assessment tricuspid regurgitation and baffle stenosis or leakage in patients.

\section{Statistical analysis}

Data are presented as mean \pm standard deviation or median (range) as specified. Demographic variables and echocardiographic parameters were compared using unpaired Student's $t$ test and Fisher's exact test where appropriate. Serum miRNA expression levels between patients and controls were compared using Mann-Whitney test.
Relationships between logarithmically transformed serum miRNA levels and systemic ventricular IVA were determined by Pearson correlation analysis. All $\mathrm{p}$ values are two-sided and a p value $<0.05$ was considered statistically significant. All statistical analyses were performed using SPSS 16.0 (SPSS Inc., Chicago IL, USA).

\section{Results}

\section{Subject characteristics}

The demographic and clinical characteristics of all subjects are summarized in Table 1 . Of the 26 patients, 22 had undergone Senning operation while 4 had Mustard procedure. Eight patients had closure of an associated ventricular septal defect. At the time of study, 5 patients were taking cardiac medications and were in New York Heart Association functional class II. The remaining 21 patients were in functional class I. There were no significant differences in age, sex distribution, and body size between patients and controls for both the cohort in the profiling study and the entire cohort included in the validation part (all $\mathrm{p}>0.05$ ).

\section{Cardiac status in patients}

Tricuspid regurgitation was severe in 1 patient, trivial to mild in 19, and absent in 6. Mild baffle leak was found in 1 patient, while mild subpulmonary stenosis was noted in 2. History of cardiac arrhythmias was documented in 4 patients, with 1 each having sinus node dysfunction, first degree heart block, atrial flutter, and infrequent ventricular ectopics. All patients were in sinus rhythm at the time of study. Compared with controls, patients had significantly

Table 1 Demographic and clinical characteristics of patients and controls

\begin{tabular}{|c|c|c|c|c|c|c|}
\hline & \multicolumn{2}{|c|}{ Microarray } & \multirow[b]{2}{*}{$p$} & \multicolumn{2}{|c|}{$q R T-P C R$ validation } & \multirow[b]{2}{*}{$p$} \\
\hline & Patients $(n=5)$ & Controls $(n=5)$ & & Patients $(n=26)$ & Controls $(n=20)$ & \\
\hline Age at study (years) & $26.5 \pm 5.1$ & $24.5 \pm 6.3$ & 0.60 & $25.3 \pm 3.2$ & $25.0 \pm 4.3$ & 0.82 \\
\hline Gender (M:F) & $3: 2$ & $3: 2$ & 1.0 & $17: 9$ & $11: 9$ & 0.82 \\
\hline $\mathrm{BMI}\left(\mathrm{kg} / \mathrm{m}^{2}\right)$ & $19.9 \pm 1.5$ & $23.3 \pm 3.9$ & 0.12 & $21.8 \pm 3.3$ & $21.6 \pm 3.3$ & 0.84 \\
\hline $\mathrm{BSA}\left(\mathrm{m}^{2}\right)$ & $1.66 \pm 0.09$ & $1.77 \pm 0.22$ & 0.30 & $1.67 \pm 0.14$ & $1.70 \pm 0.21$ & 0.57 \\
\hline Age at surgery (years) & $2.24 \pm 2.26$ & - & & $1.90 \pm 2.26$ & - & \\
\hline Type of operation (Mustard: Senning) & $1: 4$ & - & & $4: 22$ & - & \\
\hline Closure of VSD & 2 & - & & 8 & - & \\
\hline Medical treatment (n) & $(2)$ & - & & (5) & - & \\
\hline - ACEI & 2 & - & & 4 & - & \\
\hline$-A R B$ & 2 & - & & 3 & - & \\
\hline - furosemide & 1 & - & & 1 & - & \\
\hline - spironolactone & 1 & - & & 1 & - & \\
\hline - aspirin & 1 & - & & 1 & - & \\
\hline - digoxin & 0 & - & & 1 & - & \\
\hline
\end{tabular}

$A C E I:=$ angiotensin-converting enzyme inhibitors, $A R B:=$ angiotensin II receptor blockers, $B M I:=$ body mass index, $B S A:=$ body surface area, $q R T-P C R:=$ real-time quantitative reverse-transcription polymerase chain reaction, $V S D:=$ ventricular septal defect. 
reduced systemic ventricular IVA $\left(1.06 \pm 0.42 \mathrm{~m} / \mathrm{s}^{2}\right.$ vs $1.45 \pm 0.39 \mathrm{~m} / \mathrm{s}^{2}, \mathrm{p}=0.002$ ).

\section{Identification of differentially expressed serum miRNAs in patients}

Serum miRNA expression profiling was performed using serum samples from 5 patients and 5 controls matched for age and sex (Table 1). The level of RNU6B used for normalization was similar between patients and controls $(32.3 \pm 0.4$ vs $32.4 \pm 0.5, p=0.54)$. The levels of serum miRNAs differed between patients and controls as illustrated in the heat map (Figure 1). One hundred miRNAs with fold change $>1$ and RNU6B levels are shown in Additional file 2: Table S2. Using a 3-fold expression difference as a cut-off level, 23 miRNAs were found to be significantly up-regulated and 1 miRNA significantly down-regulated in patients compared with controls (Table 2). As miR-505* was expressed only in patients, the absolute fold-change could not be calculated.

\section{Larger sample size validation}

To validate the profiling results, qRT-PCR was performed to measure the serum expression levels of the 24 miRNAs in 26 patients and 20 controls. For the whole cohort, there was similarly no significant difference in RNU6B level between patients and controls $(28.7 \pm 1.3$ vs $28.8 \pm 1.6$, $\mathrm{p}=0.79$ ). Among the 23 up-regulated miRNAs, 11 were significantly elevated in patients compared with controls: miR-16, miR-106a, miR-144*, miR-18a, miR-25, miR-451, miR-486-3p, miR-486-5p, miR-505*, let-7e and miR-93 (Figure 2). However, down-regulation of miR-494 was not confirmed by qRT-PCR.

\section{Factors associated with up-regulated serum miRNAs}

For the whole cohort, IVA correlated negatively with serum miR-18a $(r=-0.45, p=0.002)$ and miR-486-5p levels $(\mathrm{r}=-0.35, \mathrm{p}=0.018)$ (Figure 3). Furthermore, serum levels of miR-18a and miR-486-5p were positively correlated $(\mathrm{r}=0.575, \mathrm{p}<0.001)$ (Additional file 3: Figure S1). None of validated miRNAs were associated with baseline

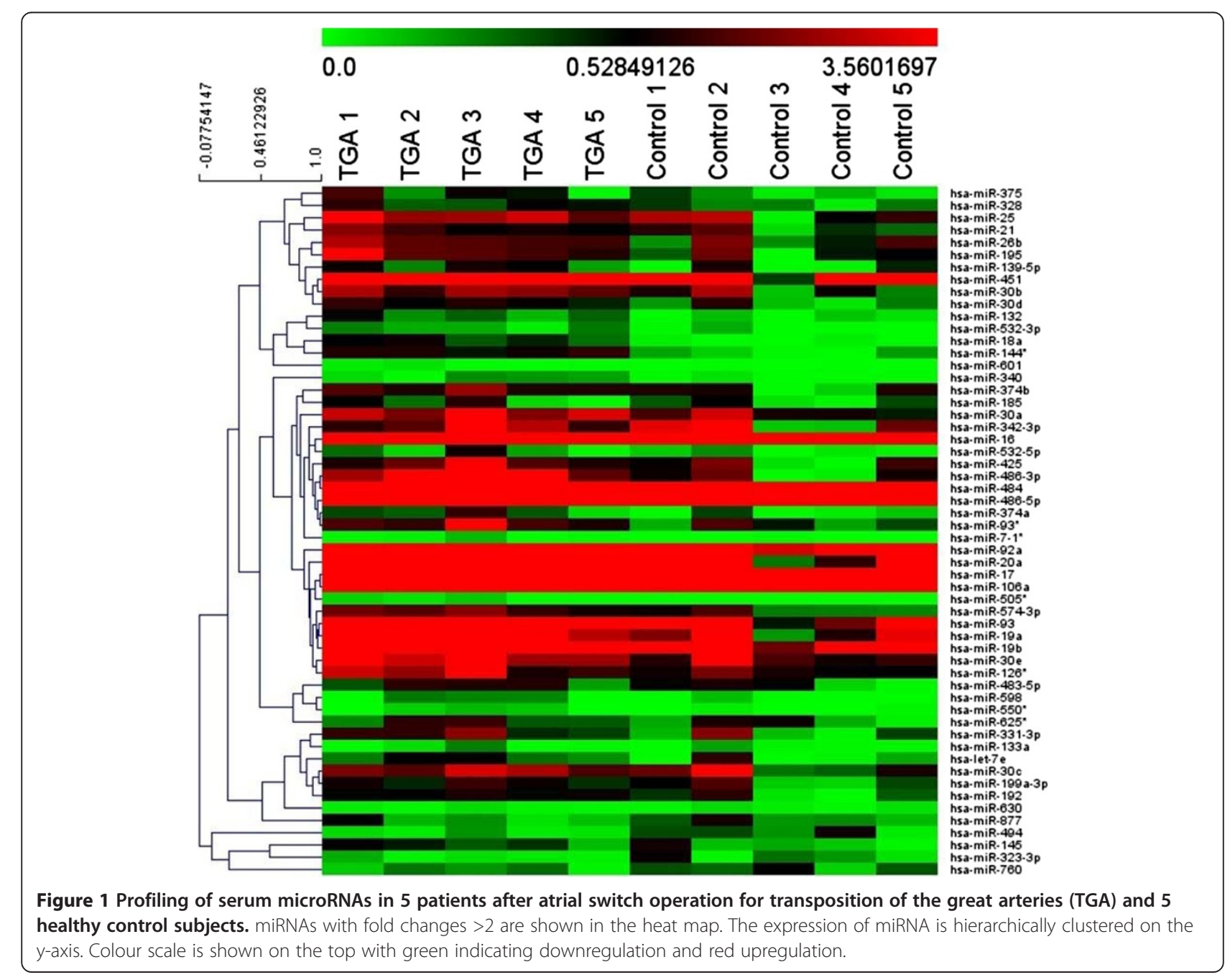




\begin{tabular}{lll}
$\begin{array}{l}\text { Table } 2 \text { Up- and down-regulated miRNAs as defined by } \\
\text { fold changes }>\mathbf{3} \text { by expression profiling in patients } \\
\text { compared with control subjects }\end{array}$ \\
\hline MicroRNA & MirBase no & Average fold change \\
\hline miR-505* & MIMAT0004776 & $\uparrow$ in patients only \\
miR-144* & MIMAT0004600 & 15.08 \\
miR-18a & MIMAT0000072 & 14.9 \\
miR-486-3p & MIMAT0004762 & 8.67 \\
miR-20a & MIMAT0000075 & 7.53 \\
miR-451 & MIMAT0001631 & 6.04 \\
miR-486-5p & MIMAT0002177 & 5.45 \\
miR-374a & MIMAT0000727 & 5.20 \\
miR-16 & MIMAT0000069 & 5.09 \\
miR-375 & MIMAT0000728 & 4.80 \\
miR-331-3p & MIMAT0000760 & 4.50 \\
Hsa-let-7e & MIMAT0000066 & 4.47 \\
miR-25 & MIMAT0000081 & 4.01 \\
miR-93* & MIMAT0004509 & 3.76 \\
miR-93 & MIMAT0000093 & 3.62 \\
miR-92a & MIMAT0000092 & 3.58 \\
miR-30b & MIMAT0000420 & 3.56 \\
miR-19a & MIMAT0000073 & 3.53 \\
miR-17-5p & 3.39 \\
miR-106a & 3.28 \\
miR-30d & 3.22 \\
miR-574-3p & 3.18 \\
miR-19b & 3.08 \\
miR-494 & 0.27 \\
\hline Is & \\
\hline
\end{tabular}

* is the notation for some of the miRs.

$\uparrow$ in patients only' literally 'increased in patients only.

demographic characteristics except for miR-144*, the level of which correlated with body mass index $(\mathrm{r}=0.32, \mathrm{p}=$ 0.03) (Additional file 4: Table S3).

\section{Discussion}

The present study demonstrates a distinct serum miRNA expression signature in adult patients with complete TGA after atrial switch operation. Expression profiling of circulating miRNA revealed significant upregulation of 23 miRNAs and downregulation of 1 miRNA, while only 11 of the upregulated miRNAs were validated in a larger patient cohort using qRT-PCR. Importantly, significant negative correlations were identified between systemic ventricular IVA, a relative load-independent index of systemic ventricular contractility, and two miRNAs miR-18a and miR-486-5p.

There is paucity of data on the expression profile of circulating microRNAs in congenital heart malformations with a systemic right ventricle. In the only study published to date, Tutarel et al. showed no difference in the levels of circulating miR-423-5p between adults after atrial repair of TGA and healthy subjects [26]. To our knowledge, this is the first study using expression profiling followed by validation of differentially expressed serum miRNAs to explore potential alteration of circulating miRNA profile in patients late after atrial switch operation.

Of the 11 validated miRNAs, several had been reported to associate with cardiovascular and cerebrovascular diseases. Up-regulation of peripheral blood let-7e has been shown in large and small artery stroke, cardioembolic stroke and stroke with undetermined causes, while expression of miR-16, miR-106a, miR-25 and miR93 were found to be differentially increased in patients with small artery stroke only [27]. In hypertensive patients, plasma expression of let-7e has been demonstrated to be elevated in profiling studies [20]. In a rodent model of pulmonary hypertension, miR-451 in lung tissues showed a strong upregulation in hypoxic samples [28], while in children with aortic stenosis undergoing aortic valve replacement, differential upregulation of ventricular let-7e and miR-93 has been reported [8].

The differentially expressed circulating miRNAs identified in the present study appear to be involved in biologic processes that are of relevance to our patients: angiogenesis (miR-16 and miR-18a) [29,30], hypoxia regulation (let-7e, miR-16, miR106a and miR-93) [31], and apoptosis and cell cycle control (miR-16) [32,33]. In this regard, it is worthwhile noting that abnormal myocardial perfusion and reduced coronary flow reserve $[34,35]$ are well documented in patients after atrial switch operation. It would also be interesting to determine the level of vascular endothelial growth factors in patients in future studies. Our recent finding of increased circulating annexin A5 lends support to possible increased apoptotic process in these patients [36] Gene prediction programmes [37] identify biological pathways of cardiac significance, which include MAPK signaling [38], Wnt signaling [39], and TGF beta signaling [40].

Progressive systemic RV dysfunction in patients after Senning and Mustard operation remains an important issue of concern [21,22]. MicroRNAs may play a role in LV remodeling process through regulating the gene networks that modulate cardiomyocyte apoptosis and myocardial fibrosis [41]. While the precise mechanism of systemic RV dysfunction remains elusive, our novel findings of negative relationships between expression of serum miR-18a and miR-486-5p and systemic ventricular IVA suggests a possible role of dysregulated microRNAs.

The contractile apparatus of the systemic right ventricle may potentially be jeopardized by ischaemia $[34,35]$ and apoptosis [36]. miR-18a has been shown to downregulate Ataxia Telangiectasia Mutated (ATM) expression and reduce DNA damage repair ability [42]. Further studies 


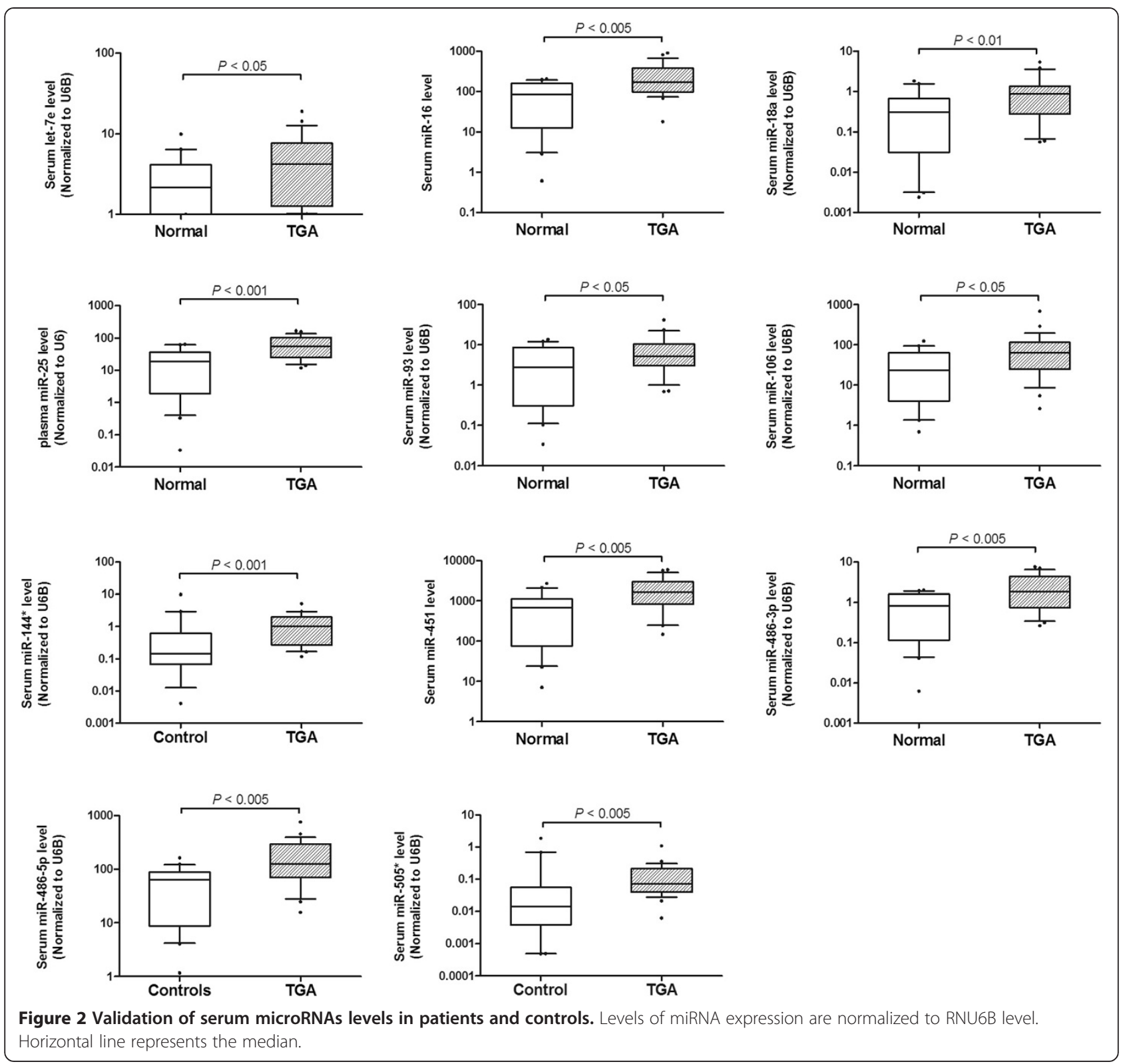

have unveiled a protective role ATM in cardiac apoptosis [43]. There are also suggestions that our other validated candidate miR-486-5p, which is enriched in cardiac and skeletal muscles, may have a role in modulating cardiac contractile function [44]. Overexpression of miR-486 has been reported to enhance muscle phosphoinositide-3kinse (PI3K)/Akt signaling by reducing the upstream negative regulator, phosphatase and tensin homolog (PTEN) [44]. Of relevance is the demonstration of decreased cardiac contractility with pharmacological inhibition of PTEN and in cardiac muscle specific PTEN knockout mice [45,46]. Furthermore, chronic overexpression of Akt has been shown to cause maladaptive hypertrophy of the left ventricle with dilation and contractile dysfunction [47]. Although we have not determined the levels of brain natriuretic peptide, a biomarker of ventricular dysfunction, in the present study, we [48] and others [49] have reported previously the elevation of brain natriuretic peptide in patients after atrial repair with impaired systemic RV function.

With regard to the cardiac extracellular matrix, the cardiomyocyte-derived miR-18a has been reported to play a role in age-related heart failure through modulation of matrix protein levels [50]. Transfection of miR-25, another of our validated miRNA candidate, in cardiac fibroblast has also been demonstrated to decrease collagen gene expression [51]. Indeed, our recent findings of increased tumour necrosis factor and absence of 

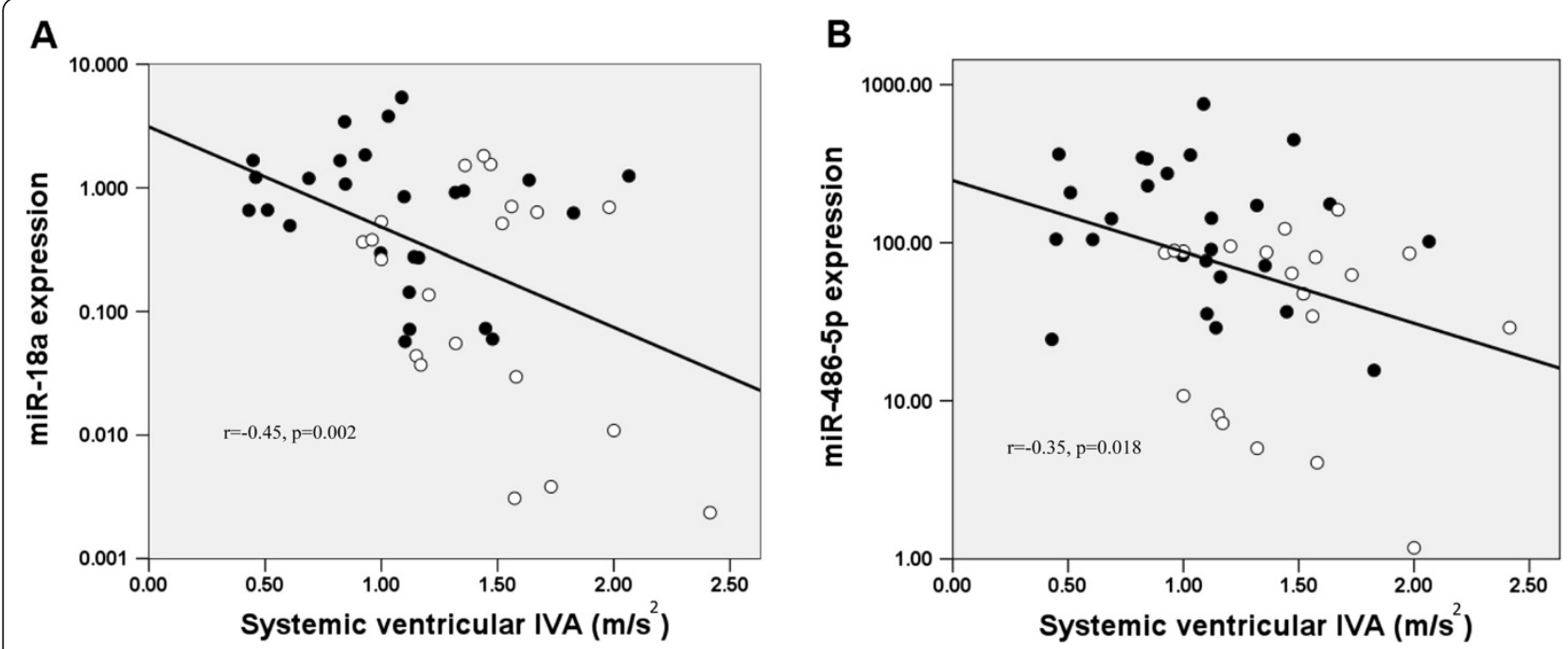

Figure 3 Scatter plots showing negative correlation between systemic ventricular myocardial acceleration during isovolumic contraction (IVA) and (A) serum miR-18a and (B) miR-486-5p expressions. Closed and open dots represent patients and controls, respectively.

increase in circulating biomarkers of collagen biosynthesis in patients with TGA after atrial switch operation implicate reduced myocardial collagen synthesis [36]. Hence, reduction of matrix tensile strength may be a cause of progressive RV dilation in post Senning and Mustard patients.

Taken together, our novel finding of a distinct circulating miRNA profile sheds light on the pathogenesis of systemic RV dysfunction in patients after atrial switch operation from an entirely new perspective. There is no doubt, however, that the findings are preliminary and that the molecular mechanisms of upregulation of circulating miRNAs in our patients require further investigations. In this regard, inclusion of additional patient cohorts with subpulmonary right ventricles operating under relatively normal pressure, as in TGA patients after arterial switch operation, and increased pressure, as those with severe pulmonary stenosis, may shed more light on the underlying mechanism. Another important limitation of the present study is that we cannot ascertain the source in our patients of the upregulated circulating miRNAs, which may occur as a result of cellular damage or secretion [52]. Nonetheless, De Rosa et al. have recently provided convincing evidence of the cardiac source of circulating miRNAs associated with acute coronary syndromes [53]. Furthermore, despite the undetermined source, circulating miR NAs may function as potential paracrine mediator of cardiovascular disease [54].

\section{Conclusion}

In conclusion, the present study provides the first evidence of an altered circulating miRNA expression profile in adult congenital heart patients with a systemic right ventricle after atrial switch operation. While we have validated the expression profiling results independently in a bigger cohort of subjects, these preliminary data need to be confirmed in a larger clinical population. Given the demonstrable relationships between serum miR-18a and miR-486-5p expressions and systemic ventricular contractility, further studies are warranted to explore the potential usefulness of circulating miRNAs as biomarkers for development of systemic RV dysfunction.

\section{Additional files}

Additional file 1: Table S1. MiRNA-specific primer sequences for qRT-PCR.

Additional file 2: Table S2. MiRNAs with fold change $>1$ and levels of RNU6B.

Additional file 3: Figure S1. Scatter plot showing a positive correlation between serum levels of miR-18a and miR-486-5p.

Additional file 4: Table S3. Correlations between miRNAs and demographic characteristics and systemic ventricular isovolumic acceleration.

\section{Competing interests}

The author(s) declare that they have no competing interests.

\section{Authors' contributions}

YFC has been involved in design of the study. CTML and PCC recruited the subjects. CTML and PCC have been involved in echocardiographic data acquisition. CTML carried out the experiments. EKON provided laboratory technical help. CTML processed the data. CTML performed the statistical analysis. YFC and CTML analysed and interpreted the data. YFC and CTML drafted and edited the manuscript. YFC, CTML, EKON and AK critically revised the manuscript. YFC supervised the study. All authors have read and agree to the manuscript as written.

\section{Author details}

${ }^{1}$ Division of Paediatric Cardiology, Department of Paediatrics and Adolescent Medicine, The University of Hong Kong, Hongkong, China. ${ }^{2}$ Department of 
Surgery, The University of Hong Kong, Hong Kong, China. ${ }^{3}$ Division of Paediatric Cardiology, Department of Paediatrics and Adolescent Medicine, The University of Hong Kong, Queen Mary Hospital, 102, Pokfulam Road, Hong Kong, China.

Received: 18 April 2013 Accepted: 13 September 2013 Published: 16 September 2013

\section{References}

1. Bartel DP: MicroRNAs: genomics, biogenesis, mechanism, and function. Cell 2004, 116:281-297.

2. Reid G, Kirschner MB, van Zandwijk N: Circulating microRNAs: association with disease and potential use as biomarkers. Crit Rev Oncol Hematol 2011, 80:193-208.

3. Lee YS, Dutta A: MicroRNAs in cancer. Annu Rev Pathol 2009, 4:199-227.

4. Liu N, Olson EN: MicroRNA regulatory networks in cardiovascular development. Dev Cell 2010, 18:510-525.

5. Wang J, Xu R, Lin F, Zhang S, Zhang G, Hu S, Zheng Z: MicroRNA: novel regulators involved in the remodeling and reverse remodeling of the heart. Cardiology 2009, 113:81-88.

6. Divakaran $\mathrm{V}$, Mann DL: The emerging role of microRNAs in cardiac remodeling and heart failure. Circ Res 2008, 103:1072-1083.

7. Bostjancic E, Zidar N, Glavac D: MicroRNA microarray expression profiling in human myocardial infarction. Dis Markers 2009, 27:255-268.

8. Ikeda S, Kong SW, Lu J, Bisping E, Zhang H, Allen PD, Golub TR, Pieske B, Pu WT: Altered microRNA expression in human heart disease. Physiol Genomics 2007, 31:367-373

9. Matkovich SJ, Van Booven DJ, Youker KA, Torre-Amione G, Diwan A, Eschenbacher WH, Dorn LE, Watson MA, Margulies KB, Dorn GW 2nd: Reciprocal regulation of myocardial microRNAs and messenger RNA in human cardiomyopathy and reversal of the microRNA signature by biomechanical support. Circulation 2009, 119:1263-1271.

10. Naga Prasad SV, Karnik S: MicroRNAs - regulators of signaling networks in dilated cardiomyopathy. J Cardiovasc Transl Res 2010, 3:225-234.

11. Carè A, Catalucci D, Felicetti F, Bonci D, Addario A, Gallo P, Bang ML, Segnalini P, Gu Y, Dalton ND, Elia L, Latronico MV, Høydal M, Autore C, Russo MA, Dorn GW 2nd, Ellingsen O, Ruiz-Lozano P, Peterson KL, Croce CM, Peschle C, Condorelli G: MicroRNA-133 controls cardiac hypertrophy. Nat Med 2007, 13:613-618.

12. Cheng Y, Ji R, Yue J, Yang J, Liu X, Chen H, Dean DB, Zhang C: MicroRNAs are aberrantly expressed in hypertrophic heart: do they play a role in cardiac hypertrophy? Am J Pathol 2007, 170:1831-1840.

13. Li P: MicroRNAs in cardiac apoptosis. J Cardiovasc Transl Res 2010, 3:219-224

14. Martin MM, Lee EJ, Buckenberger JA, Schmittgen TD, Elton TS: MicroRNA155 regulates human angiotensin II type 1 receptor expression in fibroblasts. J Biol Chem 2006, 281:18277-18284.

15. Romero DG, Plonczynski MW, Carvajal CA, Gomez-Sanchez EP, GomezSanchez CE: Microribonucleic acid-21 increases aldosterone secretion and proliferation in H295R human adrenocortical cells. Endocrinology 2008, 149:2477-2483.

16. Chen X, Ba Y, Ma L, Cai X, Yin Y, Wang K, Guo J, Zhang Y, Chen J, Guo X, L Q, Li X, Wang W, Zhang Y, Wang J, Jiang X, Xiang Y, Xu C, Zheng P, Zhang J, Li R, Zhang H, Shang X, Gong T, Ning G, Wang J, Zen K, Zhang J, Zhang CY: Characterization of microRNAs in serum: a novel class of biomarkers for diagnosis of cancer and other diseases. Cell Res 2008, 18:997-1006.

17. Gilad S, Meiri E, Yogev Y, Benjamin S, Lebanony D, Yerushalmi N, Benjamin H, Kushnir M, Cholakh H, Melamed N, Bentwich Z, Hod M, Goren Y, Chajut A: Serum microRNAs are promising novel biomarkers. PLoS One 2008, 3:e3148.

18. Wang GK, Zhu JQ, Zhang JT, Li Q, Li Y, He J, Qin YW, Jing Q: Circulating microRNA: a novel potential biomarker for early diagnosis of acute myocardial infarction in humans. Eur Heart J 2010, 31:659-666.

19. Tijsen AJ, Creemers EE, Moerland PD, de Windt LJ, van der Wal AC, Kok WE, Pinto YM: MiR423-5p as a circulating biomarker for heart failure. Circ Res 2010, 106:1035-1039.

20. Li S, Zhu J, Zhang W, Chen Y, Zhang K, Popescu LM, Ma X, Lau WB, Rong R, Y X X, Wang B, Li Y, Xiao C, Zhang M, Wang S, Yu L, Chen AF, Yang X, Cai J: Signature microRNA expression profile of essential hypertension and its novel link to human cytomegalovirus infection. Circulation 2011, 124:175-184.
21. Dos L, Teruel L, Ferreira IJ, Rodriguez-Larrea J, Miro L, Girona J, Albert DC, Gonçalves A, Murtra M, Casaldaliga J: Late outcome of Senning and Mustard procedures for correction of transposition of the great arteries. Heart 2005, 91:652-656.

22. Roos-Hesselink JW, Meijboom FJ, Spitaels SE, van Domburg R, van Rijen EH, Utens EM, McGhie J, Bos E, Bogers AJ, Simoons ML: Decline in ventricular function and clinical condition after Mustard repair for transposition of the great arteries (a prospective study of 22-29 years). Eur Heart J 2004, 25:1264-1270.

23. Derrick G, Deanfield JE: Decline in ventricular function and clinical condition after Mustard repair. Eur Heart J 2004, 25:1863-1864.

24. Ng EK, Chong WW, Jin H, Lam EK, Shin WY, Yu J, Poon TC, Ng SS, Sung J J: Differential expression of microRNAs in plasma of patients with colorectal cancer: a potential marker for colorectal cancer screening. Gut 2009, 58:1375-1381.

25. Vogel M, Schmidt MR, Kristiansen SB, Cheung M, White PA, Sorensen K, Redington AN: Validation of myocardial acceleration during isovolumic contraction as a novel noninvasive index of right ventricular contractility: comparison with ventricular pressure-volume relations in an animal model. Circulation 2002, 105:1693-1699.

26. Tutarel O, Dangwal S, Bretthauer J, Westhoff-Bleck M, Roentgen P, Anker SD, Bauersachs J, Thum T: Circulating miR-423_5p fails as a biomarker for systemic ventricular function in adults after atrial repair for transposition of the great arteries. Int I Cardiol 2011. Epub ahead of print.

27. Tan KS, Armugam A, Sepramaniam S, Lim KY, Setyowati KD, Wang CW, Jeyaseelan K: Expression profile of MicroRNAs in young stroke patients. PLoS One 2009, 4:e7689.

28. Caruso P, MacLean MR, Khanin R, McClure J, Soon E, Southgate $M$, MacDonald RA, Greig JA, Robertson KE, Masson R, Denby L, Dempsie $Y$, Long L, Morrell NW, Baker AH: Dynamic changes in lung microRNA profiles during the development of pulmonary hypertension due to chronic hypoxia and monocrotaline. Arterioscler Thromb Vasc Biol 2010, 30:716-723.

29. Dejean E, Renalier MH, Foisseau M, Agirre X, Joseph N, de Paiva GR, Al Saati T, Soulier J, Desjobert C, Lamant L, Prósper F, Felsher DW, Cavaillé J, Prats H, Delsol G, Giuriato S, Meggetto F: Hypoxia-microRNA-16 downregulation induces VEGF expression in anaplastic lymphoma kinase (ALK)-positive anaplastic large-cell lymphomas. Leukemia 2011, 25:1882-1890

30. Doebele C, Bonauer A, Fischer A, Scholz A, Reiss Y, Urbich C, Hofmann WK Zeiher AM, Dimmeler S: Members of the microRNA-17-92 cluster exhibit a cell-intrinsic antiangiogenic function in endothelial cells. Blood 2010, 115:4944-4950.

31. Kulshreshtha R, Davuluri RV, Calin GA, Ivan M: A microRNA component of the hypoxic response. Cell Death Differ 2008, 15:667-671.

32. Liu Q, Fu H, Sun F, Zhang H, Tie Y, Zhu J, Xing R, Sun Z, Zheng X: miR-16 family induces cell cycle arrest by regulating multiple cell cycle genes. Nucleic Acids Res 2008, 36:5391-5404.

33. Cimmino A, Calin GA, Fabbri M, lorio MV, Ferracin M, Shimizu M, Wojcik SE, Ageilan RI, Zupo S, Dono M, Rassenti L, Alder H, Volinia S, Liu CG, Kipps TJ, Negrini M, Croce CM: miR-15 and miR-16 induce apoptosis by targeting BCL2. Proc Natl Acad Sci U S A 2005, 102:13944-13949.

34. Millane T, Bernard EJ, Jaeggi E, Howman-Giles RB, Uren RF, Cartmill TB, Hawker RE, Celermajer DS: Role of ischemia and infarction in late right ventricular dysfunction after atrial repair of transposition of the great arteries. J Am Coll Cardiol 2000, 35:1661-1668.

35. Singh TP, Humes RA, Muzik O, Kottamasu S, Karpawich PP, Di Carli MF: Myocardial flow reserve in patients with a systemic right ventricle after atrial switch repair. J Am Coll Cardiol 2001, 37:2120-2125.

36. Lai CT, Chow PC, Wong SJ, Chan KW, Cheung YF: Circulating annexin A5 levels after atrial switch for transposition of the great arteries: relationship with ventricular deformation and geometry. PLoS One 2012, 7:e52125.

37. Papadopoulos GL, Alexiou P, Maragkakis M, Reczko M, Hatzigeorgiou AG: DIANA-mirPath: Integrating human and mouse microRNAs in pathways. Bioinformatics 2009, 25:1991-1993.

38. Rose BA, Force $T$, Wang Y: Mitogen-activated protein kinase signaling in the heart: angels versus demons in a heart-breaking tale. Physiol Rev 2010, 90:1507-1546.

39. Naito AT, Shiojima I, Komuro I: Wnt signaling and aging-related heart disorders. Circ Res 2010, 107:1295-1303. 
40. Leask A: TGFbeta, cardiac fibroblasts, and the fibrotic response. Cardiovasc Res 2007, 74:207-212.

41. Shah AM, Mann DL: In search of new therapeutic targets and strategies for heart failure: recent advances in basic science. Lancet 2011, 378:704-712.

42. Song L, Lin C, Wu Z, Gong H, Zeng Y, Wu J, Li M, Li J: miR-18a impairs DNA damage response through downregulation of ataxia telangiectasia mutated (ATM) kinase. PLoS One 2011, 6:e25454.

43. Foster $C R$, Singh $M$, Subramanian $V$, Singh $K$ : Ataxia telangiectasia mutated kinase plays a protective role in beta-adrenergic receptor-stimulated cardiac myocyte apoptosis and myocardial remodeling. Mol Cell Biochem 2011, 353:13-22.

44. Small EM, O'Rourke JR, Moresi V, Sutherland LB, McAnally J, Gerard RD, Richardson JA, Olson EN: Regulation of PI3-kinase/Akt signaling by muscleenriched microRNA-486. Proc Natl Acad Sci U S A 2010, 107:4218-4223.

45. Crackower MA, Oudit GY, Kozieradzki I, Sarao R, Sun H, Sasaki T, Hirsch E, Suzuki A, Shioi T, Irie-Sasaki J, Sah R, Cheng HY, Rybin VO, Lembo G, Fratta L, Oliveira-dos-Santos AJ, Benovic JL, Kahn CR, Izumo S, Steinberg SF, Wymann MP, Backx PH, Penninger JM: Regulation of myocardial contractility and cell size by distinct PI3K-PTEN signaling pathways. Cell 2002, 110:737-749.

46. Zu L, Shen Z, Wesley J, Cai ZP: PTEN inhibitors cause a negative inotropic and chronotropic effect in mice. Eur J Pharmacol 2011, 650:298-302.

47. Shiojima I, Sato K, Izumiya Y, Schiekofer S, Ito M, Liao R, Colucci WS, Walsh K: Disruption of coordinated cardiac hypertrophy and angiogenesis contributes to the transition to heart failure. J Clin Invest 2005, 115:2108-2118

48. van Almen $G C$, Verhesen $W$, van Leeuwen RE, van de Vrie M, Eurlings $C$, Schellings MW, Swinnen M, Cleutjens JP, van Zandvoort MA, Heymans S, Schroen B: MicroRNA-18 and microRNA-19 regulate CTGF and TSP-1 expression in age-related heart failure. Aging Cell 2011, 10:769-779.

49. Chow PC, Cheung EW, Chong CY, Lun KS, Yung TC, Wong KT, Chau AK, Cheung YF: Brain natriuretic peptide as a biomarker of systemic right ventricular function in patients with transposition of great arteries after atrial switch operation. Int J Cardiol 2008 2007, 127:192-197.

50. Vogt M, Kühn A, Wiese J, Eicken A, Hess J, Vogel M: Reduced contractile reserve of the systemic right ventricle under dobutamine stress is associated with increased brain natriuretic peptide levels in patients with complete transposition after atrial repair. Eur J Echocardiogr 2009, 10:691-694.

51. Divakaran V, Adrogue J, Ishiyama M, Entman ML, Haudek S,

Sivasubramanian N, Mann DL: Adaptive and maladptive effects of SMAD3 signaling in the adult heart after hemodynamic pressure overloading. Circ Heart Fail 2009, 2:633-642.

52. Laterza OF, Lim L, Garrett-Engele PW, Vlasakova K, Muniappa N, Tanaka WK, Johnson JM, Sina JF, Fare TL, Sistare FD, Glaab WE: Plasma MicroRNAs as sensitive and specific biomarkers of tissue injury. Clin Chem 2009, 55:1977-1983

53. De Rosa S, Fichtlscherer S, Lehmann R, Assmus B, Dimmeler S, Zeiher AM: Transcoronary concentration gradients of circulating microRNAs. Circulation 2011, 124:1936-1944.

54. Gupta SK, Bang C, Thum T: Circulating microRNAs as biomarkers and potential paracrine mediators of cardiovascular disease. Circ Cardiovasc Genet 2010, 3:484-488.

doi:10.1186/1471-2261-13-73

Cite this article as: Lai et al:: Circulating microRNA expression profile and systemic right ventricular function in adults after atrial switch operation for complete transposition of the great arteries. BMC Cardiovascular Disorders 2013 13:73.

\section{Submit your next manuscript to BioMed Central and take full advantage of:}

- Convenient online submission

- Thorough peer review

- No space constraints or color figure charges

- Immediate publication on acceptance

- Inclusion in PubMed, CAS, Scopus and Google Scholar

- Research which is freely available for redistribution 